\title{
ANALISIS PERBANDINGAN PELACAKAN OBJEK MENGGUNAKAN ALGORITMA HORN-SCHUNCK DAN LUCAS- KANADE
}

\author{
Wahyu Supriyatin \\ Fakultas IImu Komputer dan Teknologi Informasi, Universitas Gunadarma, Depok, Indonesia \\ Corresponding Author: ayu ws@staff.gunadarma.ac.id
}

\begin{abstract}
Abstrak
Pelacakan objek merupakan pengembangan dari computer vision. Computer vision mirip dengan mata manusia memiliki fungsi sebagai penglihatan. Kesulitan untuk mendeteksi keberadaan suatu objek sehingga dibuat aplikasi pelacakan objek. Pelacakan objek biasanya dimanfaatkan dalam gps track pada pesawat, gps track pada mobil, alat pendeteksi tubuh manusia dibandara, alat pengatur jumlah kendaraan yang melintas dan alat navigasi pada robot. Penelitian ini bertujuan untuk mengidentifikasi objek yang melintas dalam suatu frame. Penelitian ini juga dapat menghitung jumlah objek yang melintas dalam satu frame. Pelacakan objek dilakukan dengan membandingkan dua algoritma yaitu Horn-Schunck dan Lucas-Kanade. Kedua algoritma menggunakan pengujian Source Block Parameter dan Function Block Parameter. Pengujian dilakukan dengan resolusi video $120 \times 160$ dan posisi kamera pengambilan pada jarak 2-4 m. Pengujian pelacakan objek dilakukan dalam durasi 110-120 detik. Tahapan pelacakan objek thresholding, filtering dan region berhasil memperoleh video biner objek. Pengujian algoritma Lucas-Kanade memiliki waktu yang cepat dalam mengidentifikasi objek dibandingkan algoritma Horn-Schunck.
\end{abstract}

Kata kunci: Horn-Schunck, Lucas-Kanade, Optical Flow, Pelacakan Objek

\begin{abstract}
Object tracking one of computer vision. Computer vision similar to human eye function. The difficulty is to detect presence an object and object tracking application made. Object tracking used in aircraft, track cars, human body detectors at airports, a regulator the number of vehicles pass and navigation tools on robots. This study is to identify objects that pass in frame. This research also count the number of objects that pass in one frame. Object tracking done by comparing two algorithms namely Horn-Schunck and Lucas-Kanade. Both algorithms tested using the Source Block Parameter and Function Block Parameter. The test carried out with video resolution $120 \times 160$ and the position camera is 2-4 m. The object tracking test is conducted in the duration of 110-120 seconds. Stages tracking object was thresholding, filtering and region successfully obtain object binary video. The Lucas-Kanade has faster in identifying objects compared to the Horn-Schunck algorithm.
\end{abstract}

Keywords: Horn-Schunck, Lucas-Kanade, Object Tracking, Optical Flow

\section{Pendahuluan}

Citra digital didapat dari sekumpulan gambar ataupun video [1]. Gambar atau video merupakan hasil rekaman kamera seperti IP Camera, CCTV, digital camera dan handphone camera [1]. Gambar atau video yang dihasilkan tidak memiliki kualitas yang baik karena pengaruh spesifikasi kamera yang rendah, letak kamera yang tidak tepat, pencahayaan yang kurang serta terdapat noise atau gangguan saat merekam [1]. Berkembangnya teknologi membuat teknik pengolahan citra digital berkembang menjadi computer vision [1].

Computer vision merupakan proses otomatis menginterprestasikan sejumlah besar proses untuk persepsi visual seperti akuisisi, pengolahan citra, klasifikasi, pengenalan (recognition) dan membuat keputusan [2]. Computer vision digunakan untuk mengolah gambar dan video untuk memperoleh hasil yang dapat dianalisa [1]. Computer vision memiliki fungsi yang sama dengan mata manusia dalam hal penglihatan [1]. Pelacakan objek merupakan salah satu penerapan dari Analisis Perbandingan Pelacakan Objek Menggunakan Algoritma Horn-Schunck dan Lucas-Kanade (Wahyu Supriyatin) 
aplikasi computer vision untuk mendeteksi pergerakan. Banyak sekali algoritma yang dapat digunakan untuk melakukan pelacakan suatu objek, antara lain algoritma Optical Flow.

Algoritma Optical Flow merupakan salah satu algoritma pendekatan berbasis computer vision yang efisien digunakan untuk melacak pergerakan objek dengan tepat [3]. Optical Flow adalah aliran pergerakan dari sebuah objek yang bergerak berdasarkan turunan intensitas cahayanya [1]. Optical Flow mempelajari gerakan relatif benda dari berbagai urutan frame dengan berdasarkan pergerakan kecepatan objek dan perubahan iluminasi [3]. Teknik Optical Flow dapat diklasifikasikan menjadi dua tipe yaitu Space Optical Flow dan Dense Optical Flow [3]. Algoritma yang termasuk dalam Space Optical Flow adalah Lucas-Kanade, Horn-Schunck dan BuxtonBuxton [3]. Algoritma Space Optical Flow merupakan algoritma pelacakan dengan melihat bagian tertentu yang akan diteliti seperti sudut objek, tepi objek ataupun bagian lain dari objek yang ingin diamati [3].

Algoritma Horn-Schunck merupakan algoritma pelacakan objek bergerak didalam video dengan memberikan urutan pergerakan [4]. Algoritma Horn-Schunck dapat mengasumsikan nilai penghalusan di sekitaran gambar, sehingga dapat menghasilkan kepadatan nilai vektor yang tinggi [4]. Faktor kepadatan vektor membuat adanya informasi yang hilang sekitar benda homogen dengan pergerakannya dan lebih sensitif terhadap suara bising [4].

Algoritma Lucas-Kanade merupakan perpindahan konten gambar antara dua instance terdekat dan konstan dalam lingkungan titik yang dipertimbangkan [5]. Algoritma Lucas-Kanade mengasumsikan titik yang dilacak dan titik tetangga dari titik yang dilacak memiliki nilai intensitas yang sama [6]. Lucas-Kanade memiliki perpindahan posisi titik yang dilacak dari frame ke frame adalah kecil [6]. Posisi, arah gerak, besar pergerakan yang dilakukan dan kecepatan gerak dari titik yang dilacak pada frame dapat diukur [6].

Pelacakan objek diperlukan untuk mengenali dan mengidentifkasi objek yang melintas dalam satu frame. Pelacakan objek melihat aspek kecepatan durasi waktu dalam mengenali objek, ketepatan dalam mengenali bentuk objek, ukuran resolusi objek yang digunakan, letak kamera saat pengambilan objek serta kemampuan algoritma filtering yang digunakan untuk menghilangkan noise yang ada disekitaran objek baik background maupun foreground.

Penelitian ini bertujuan untuk melakukan perbandingan pelacakan objek antara dua algoritma pelacakan pada algoritma Optical Flow. Algoritma yang digunakan sebagai perbandingan adalah algoritma Horn-Schunck dan algoritma Lucas-Kanade. Algoritma digunakan untuk mendeteksi objek bergerak (video) yang diambil dengan menggunakan kamera diam pada suatu posisi. Kecepatan waktu pelacakan akan menjadi nilai yang diamati dalam penelitian ini selain ketepatan dalam mengidentifikasi bentuk objek biner yang diperoleh.

Penelitian sebelumnya tentang pelacakan objek adalah Supriyatin tahun 2019 [7], dalam penelitian pelacakan objek dengan menggunakan perbandingan antara algoritma Optical Flow dan Background Estimation pada kamera bergerak diperoleh bahwa algoritma Optical Flow lebih baik dalam mengidentifikasi objek yang melintas dibandingkan dengan algoritma Background Estimation. Dengan menggunakan kamera bergerak objek berhasil dideteksi dan dikenali dengan menggunakan algoritma Optical Flow.

Penelitian tentang perbandingan pelacakan objek menggunakan algoritma Optical Flow dan algoritma Background Estimation pada kamera diam yang diletakkan dalam suatu posisi pernah dilakukan oleh Supriyatin, 2018 [8]. Dalam penelitian yang dilakukan ternyata algoritma Optical Flow dapat mengidentifikasi objek lebih jelas dan lebih cepat dibandingkan dengan algoritma Background Estimation. Tampak bahwa waktu yang dibutuhkan dalam mengenali objek untuk Optical Flow kurang dari 100 detik, jauh berbeda dengan algoritma Background Estimation yang selalu lebih dari 100 detik dalam mengenali objek.

Tahun 2016, Supriyatin [9] dalam penelitiannya tentang analisis perbandingan pelacakan objek dengan menggunakan Optical Flow pada dua kamera yang berbeda yaitu kamera diam yang diletakkan pada satu posisi dan kamera bergerak yang mengikuti pergerakan objek. Dengan menggunakan algoritma Optical Flow dengan kondisi perbedaan posisi kamera ternyata untuk posisi kamera diam objek lebih berhasil dideteksi dan dikenali. Sedangkan dengan menggunakan kamera bergerak, objek sulit dideteksi dan tidak terkenali.

Sutanty tahun 2016, [10] dalam penelitian tentang perbandingan algoritma Optical Flow dan Background Estimation untuk mendeteksi objek pada video ternyata algoritma Optical Flow berhasil akurat dalam melakukan perhitungan objek dibandingkan dengan Background 
Estimation. Proses penangkapan objek bergerak lebih cepat dilakukan Optical Flow dengan jumlah frame 14 citra frame/detik dibandingkan dengan Background Estimation.

Penelitian tentang deteksi dan pelacakan perpindahan objek dengan menggunakan Hybrid model yaitu kombinasi GMM dan Optical Flow (Horn-Schunck) dilakukan oleh Suzan tahun 2017 [4]. Background sutraction merupakan cara yang paling cepat untuk mendeteksi pergerakan objek dengan foreground substraction dari background. Background substraction dilakukan dengan menggunakan GMM dan pelacakan objek dideteksi dengan menggunakan Optical Flow. Optical Flow yang digunakan dalam penelitian untuk melacak objek adalah Horn-Schunck. Dengan penggabungan kedua model hybrid ini maka dapat menghasilkan pelacakan objek yang baik dan tepat.

\section{Metode Penelitian}

Metode yang digunakan dalam penelitian adalah metode pengumpulan data dengan melihat pada library research. Mempelajari tools yang digunakan dalam pelacakan objek pada Simulink Matlab. Mencari video pelacakan objek dengan mengambil secara langsung dan melalui library Matlab.

Analisis perbandingan pelacakan objek dalam penelitian ini membandingkan dua buah algoritrma Optical Flow, yaitu algoritma Horn-Schunck dan algoritma Lucas-Kanade. Perbandingan pelacakan dilakukan dengan melihat durasi waktu yang dihasilkan kedua algoritma tersebut dalam mengenali objek. Gambar 1 merupakan tahapan dari penelitian perbandingan pelacakan objek kedua algoritma.

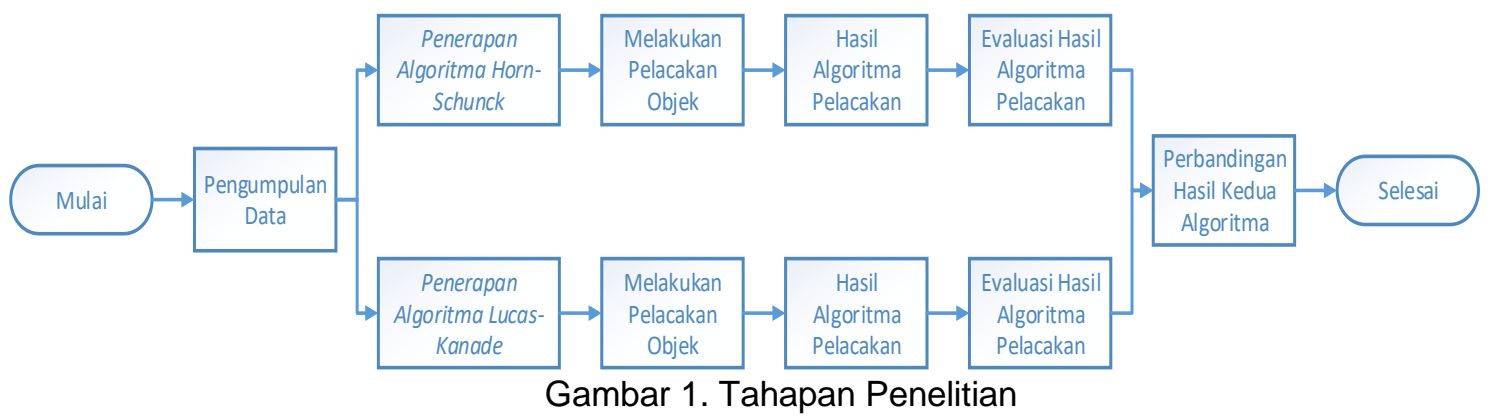

Algoritma Optical Flow adalah metode yang digunakan untuk memperkirakan pergerakan sector pada setiap frame dalam urutan video [7]. Optical Flow akan merepresentasikan gerakan dalam aliran sector kemudian menghitung nilai koordinat centroid untuk menghitung kecepatan kendaraan yang sedang bergerak [7].

Algoritma Horn-Schunck adalah algoritma klasik dalam melakukan estimasi algoritma Optical Flow [11]. Algoritma ini mengasumsikan suatu sistem kelancaraan dalam frame yang ada, melakukan minimalisasi distrosi dalam flow dan memilih solusi yang lebih lancar [11] [12]. Gambar 2 adalah algoritma Horn-Schunck yang digunakan dalam pelacakan objek.

Tahapan algoritma Horn-Schunck dalam mengenali objek pada Gambar 2 adalah :

1. Mulai.

2. Membaca objek: Membanggil video yang akan diolah dengan resolusi $120 \times 160$ dan format warna RGB (Red, Green, Blue).

3. Melakukan konversi parameter video ke Intensity: Mengubah format video dari video RGB ke video Intensity.

4. Melakukan Algoritma Optical Flow (Horn-Schunck): Menentukan nilai Function Block Parameter, membuat nilai $\mathrm{N}$ frame dalam kondisi 1, membuat nilai optical flow antara current frame dan $N$ frame back, menentukan nilai smoothness factor dalam nilai 1 dan menentukan nilai iterations dalam algoritma yaitu 10 .

5. Thresholding dan Region Filtering:

a. Thresholding: Melakukan segmentasi video untuk mengenali bentuk video. Melihat nilai intensitas piksel dan derajat keabuan sehingga membuat video menjadi bentuk biner. 
Threshold dilakukan dengan menggunakan Mean Velocity Threshold dengan melihat nilai per frame.

b. Median Filter: Memisahkan atau mengelompokkan hasil segmentasi video (video biner) dengan noise. Menyaring untuk menghilangkan noise yang ada pada video.

c. Region Filtering: Melakukan ekstraksi analisis untuk matrik dan vektor yang diperoleh. Mengelompokkan objek dengan berdasarkan bentuk dan membuang noise yang ada.

6. Tampilkan hasil pengenalan objek:

a. Video Original: Video awal dalam bentuk RGB

b. Video Motion Vector. Menentukan nilai piksel matrik dan vektor yang diperoleh dari region filtering.

c. Video Threshold: Video hasil dari thresholding dan median filter. Video yang sudah di segmentasi menjadi video biner dan dipisahkan dari noise yang ada dalam video.

d. Video Result: Video akhir dalam bentuk RGB yang sudah di segmentasi dengan thresholding, sudah dibersihkan dari noise yang ada disekitaran objek dengan median filter dan pengenalan bentuk objek dengan menggunakan nilai matrik dan vektor dari objek dengan kondisi $n$ frame yang diberikan.

7. Selesai.

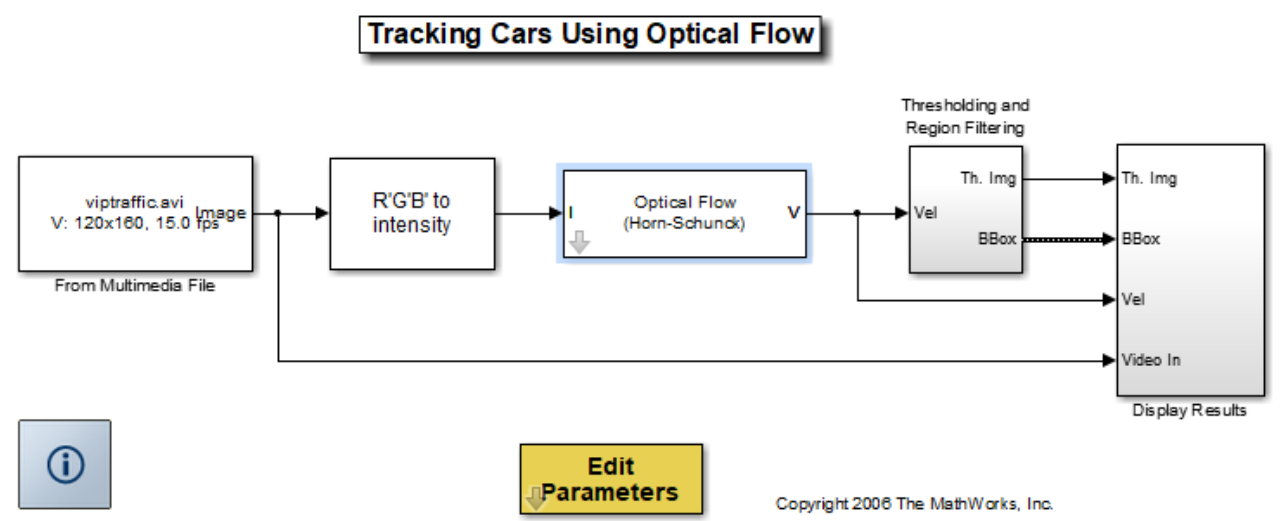

Gambar 2. Algoritma Horn-Schunck

Algoritma Lucas-Kanade adalah metode diferensial yang banyak digunakan untuk estimasi aliran optic [5]. Algoritma Lucas-Kanade digunakan untuk menyelesaikan ambiguitas inheren dari persamaan aliran optic [5]. Algoritma Lucas-Kanade diasumsikan bahwa titik yang dilacak dan titik-titik tetangga dari titik yang dilacak memiliki nilai intensitas yang sama dari frame ke frame, serta perpindahan posisi titik yang dilacak dari frame ke frame adalah kecil [6]. Gambar 3 adalah algoritma Lucas-Kanade yang digunakan dalam pengenalan objek.

Tahapan algoritma Lucas-Kanade dalam mengenali objek pada Gambar 3 adalah :

1. Mulai.

2. Membaca objek: Membanggil video yang akan diolah dengan resolusi $120 \times 160$ dan format warna RGB (Red, Green, Blue).

3. Melakukan konversi parameter video ke Intensity : Mengubah format video dari video RGB ke video Intensity.

4. Melakukan Algoritma Optical Flow (Lucas-Kanade) : Menentukan nilai Function Block Parameter, membuat nilai $\mathrm{N}$ frame dalam kondisi 1, membuat nilai optical flow antara current frame dan $N$ frame back, menentukan nilai thresholding untuk noise kurang dari 0,0050.

5. Thresholding dan Region Filtering:

a. Thresholding : Melakukan segmentasi video untuk mengenali bentuk video. Melihat nilai intensitas piksel dan derajat keabuan sehingga membuat video menjadi bentuk biner. 
Threshold dilakukan dengan menggunakan Mean Velocity Threshold dengan melihat nilai per frame.

b. Median Filter : Memisahkan atau mengelompokkan hasil segmentasi video (video biner) dengan noise. Menyaring untuk menghilangkan noise yang ada pada video.

c. Region Filtering : Melakukan ekstraksi analisis untuk matrik dan vektor yang diperoleh. Mengelompokkan objek dengan berdasarkan bentuk dan membuang noise yang ada.

6. Tampilkan hasil pengenalan objek :

a. Video Original : Video awal dalam bentuk RGB

b. Video Motion Vector: Menentukan nilai piksel matrik dan vektor yang diperoleh dari region filtering.

c. Video Threshold : Video hasil dari thresholding dan median filter. Video yang sudah di segmentasi menjadi video biner dan dipisahkan dari noise yang ada dalam video.

d. Video Result : Video akhir dalam bentuk RGB yang sudah di segmentasi dengan thresholding, sudah dibersihkan dari noise yang ada disekitaran objek dengan median filter dan pengenalan bentuk objek dengan menggunakan nilai matrik dan vektor dari objek dengan kondisi $n$ frame yang diberikan.

7. Selesai.

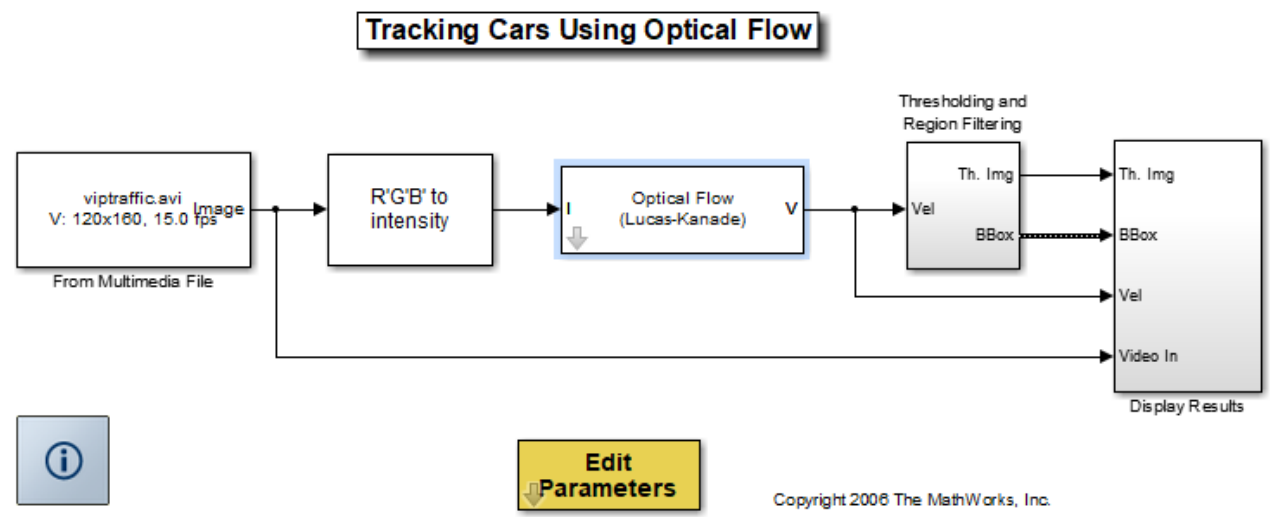

Gambar 3. Algoritma Lucas-Kanade

Perbedaan proses dan hasil antara kedua algoritma yang digunakan adalah :

1. Algoritma Horn-Schunck

a. Proses : nilai $\mathrm{N}$ frame dalam kondisi 1, nilai optical flow antara current frame dan $N$ frame back, nilai smoothness factor $=1$ dan nilai interactions sebanyak 10 .

b. Hasil : video biner hasil thresholding sebagai bentuk pelacakan objek dan waktu mengenali bentuk objek yang lebih lama dari algoritma Lucas-Kanade.

2. Algoritma Lucas-Kanade

a. Proses : nilai $\mathrm{N}$ frame dalam kondisi 1 , nilai optical flow antara current frame dan $N$ frame back dan nilai thresholding $<0,0050$.

b. Hasil : video biner hasil thresholding sebagai bentuk pelacakan objek dan waktu mengenali bentuk objek yang lebih cepat dari algoritma Horn-Schunck.

\section{Hasil dan Pembahasan}

Penelitian pelacakan objek ini membandingkan dua algoritma dalam Optical Flow yaitu algoritma Horn-Schunck dan algoritma Lucas-Kanade. Pelacakan objek dilakukan dengan menggunakan objek bergerak yang digunakan untuk melacak dan mengenali bentuk dari objek yang diminta. Video yang digunakan dalam penelitian berjumlah dua buah dengan ketentuan ukuran sebagai berikut :

1. Video Viptraffic. avi (resolusi $=120 \times 160$; frame $=15.0 \mathrm{fps}$ )

2. Video Vipmen.avi (resolusi $=120 \times 160$; frame $=30.0 \mathrm{fps}$ ) 
Kedua video yang digunakan dalam penelitian diambil dengan menggunakan kamera diam yang diletakkan pada satu posisi. Sehingga yang mengalami pergerakan hanya objek yang diamati dalam penelitian. Video pertama berupa video dengan objek kendaraan dan video kedua adalah video dengan objek manusia. Video yang digunakan dalam penelitian diperoleh dari library Matlab. Perbandingan kedua algoritma Optical Flow dilakukan pada parameter yang sama. Parameter yang digunakan sebagai pembanding dalam penelitian ini adalah :

1. Source Block Parameter

2. Function Blok Parameter

Hasil yang diperoleh pada penelitian pelacakan objek dengan menggunakan kamera diam berupa empat buah keluaran yaitu :

1. Video Original

2. Video Motion Vector

3. Video Threshold

4. Video Results

Kondisi yang digunakan dalam penelitian untuk kedua objek yang digunakan dalam pelacakan adalah :

1. Video Viptraffic.avi (kamera yang digunakan untuk mengambil objek memiliki jarak $4 \mathrm{~m}$; kecepatan pergerakan objek $60-80 \mathrm{~m} / \mathrm{s}$ )

2. Video Vipmen.avi (kamera yang digunakan untuk mengambil objek memiliki jarak $2 \mathrm{~m}$; kecepatan pergerakan objek $1-2 \mathrm{~km} / \mathrm{jam}$ )

Tabel perbandingan parameter yang digunakan dalam penelitian dan simulasi untuk uji coba dapat dilihat pada Tabel 1. Parameter yang digunakan untuk algoritma Horn-Schunck dan LucasKanade memiliki simulasi parameter yang sama.

Tabel 1. Parameter Simulasi

\begin{tabular}{|c|c|c|}
\hline Jenis Parameter & Algoritma Horn-Schunck & Algoritma Lucas-Kanade \\
\hline $\begin{array}{l}\text { Source Block Parameter } \\
\text { (Multimedia File) }\end{array}$ & $\begin{array}{l}\text { - Number of times to play file } \\
\text { : inf } \\
\text { - Output color format : RGB } \\
\text { - Image signal : One } \\
\text { multidimensional signal } \\
\text { - Video output data type : } \\
\text { single }\end{array}$ & $\begin{array}{l}\text { - Number of times to play } \\
\text { file : inf } \\
\text { - Output color format : RGB } \\
\text { - Image signal : One } \\
\text { multidimensional signal } \\
\text { - Video output data type : } \\
\text { single }\end{array}$ \\
\hline $\begin{array}{l}\text { Function Block Parameter } \\
\text { (Color Space Conversion) }\end{array}$ & $\begin{array}{l}\text { - Conversion video : RGB to } \\
\text { intensity } \\
\text { - Image signal : One } \\
\text { multidimensional signal }\end{array}$ & $\begin{array}{l}\text { - Conversion video : RGB } \\
\text { to intensity } \\
\text { - Image signal : One } \\
\text { multidimensional signal }\end{array}$ \\
\hline $\begin{array}{c}\text { Function Block Parameter } \\
\text { (Algorithm) }\end{array}$ & $\begin{array}{l}\text { - Computer optical flow } \\
\text { between : Current frame } \\
\text { and } N \text {-th frame back } \\
\text { - } N \text { frame : } 1 \\
\text { - Velocity output : Horizontal } \\
\text { and vertical components in } \\
\text { complex form }\end{array}$ & $\begin{array}{l}\text { - Computer optical flow } \\
\text { between : Current frame } \\
\text { and N-th frame back } \\
\text { - N frame : } 1 \\
\text { - Velocity output } \\
\text { Horizontal and vertical } \\
\text { components in complex } \\
\text { form }\end{array}$ \\
\hline
\end{tabular}

Gambar 4 sampai dengan gambar 7 merupakan hasil pelacakan dari kedua algoritma dengan simulasi parameter yang diberikan pada Tabel 1. Pengujian yang dilakukan menghasilkan video threshold dan video result seperti terlihat pada gambar 4 sampai gambar 7 . Jumlah objek yang berhasil terdeteksi dalam frame dihitung mulai dari berapa banyak objek yang melintas dalam garis batas pada hasil video result di point $\mathrm{c}$. 


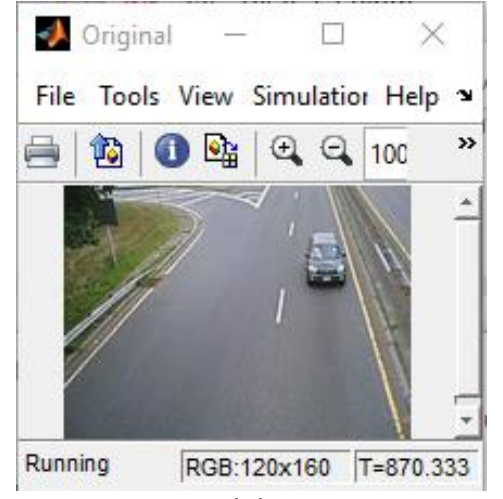

(a)

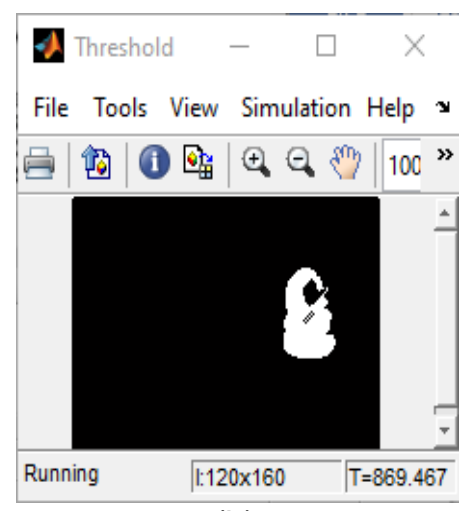

(b)

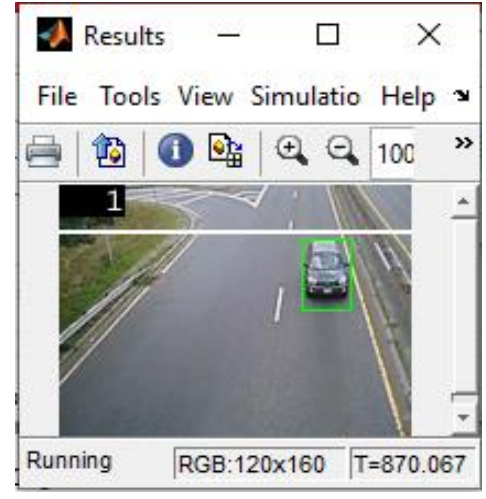

(c)

Gambar 4. Video 1 : Viptrafic.avi dengan algoritma Horn-Schunck (a). Video original (b). Video threshold (c). Video results

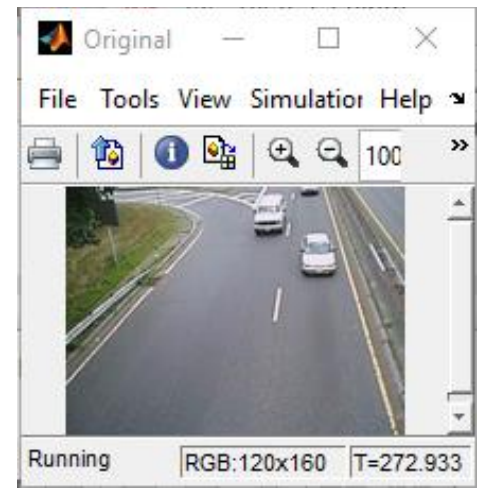

(a)

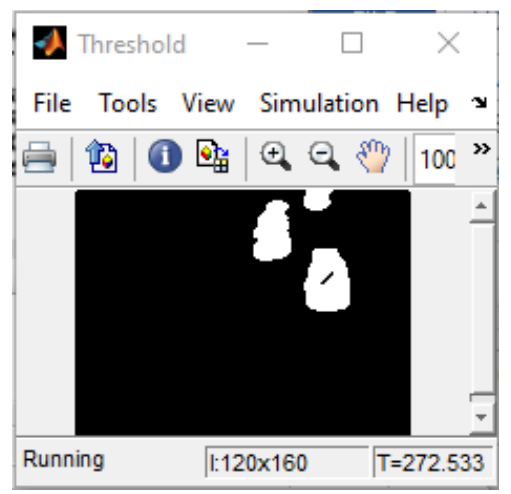

(b)

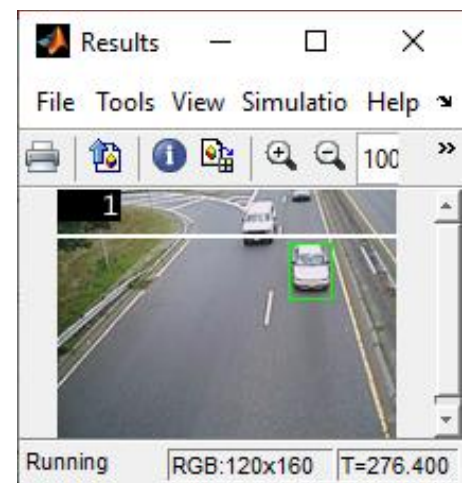

(c)

Gambar 5. Video 1 : Viptrafic.avi dengan algoritma Lucas-Kanade (a). Video original (b). Video threshold (c). Video results

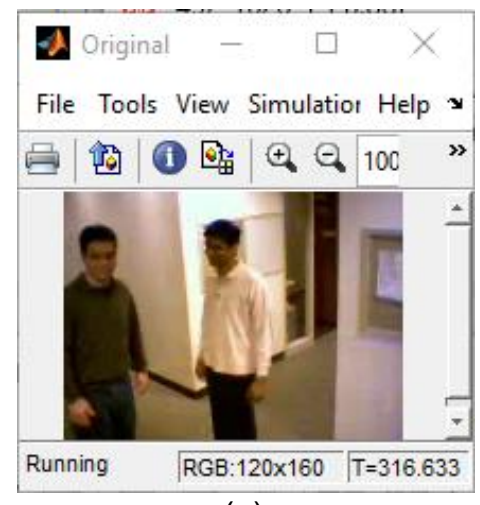

(a)



(b)

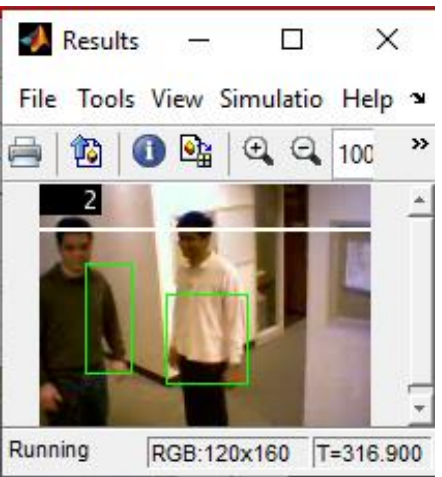

(c)

Gambar 6. Video 2 : Vipmen.avi dengan algoritma Horn-Schunck (a). Video original (b). Video threshold (c). Video results 


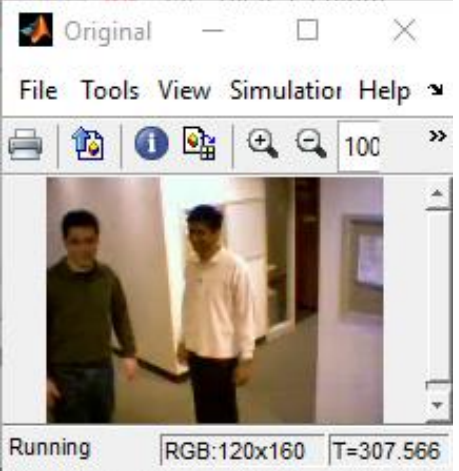

(a)

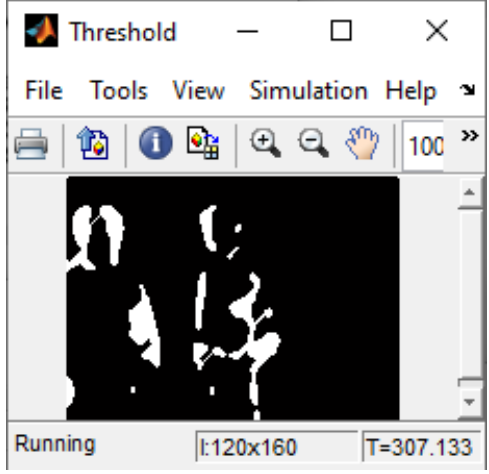

(b)

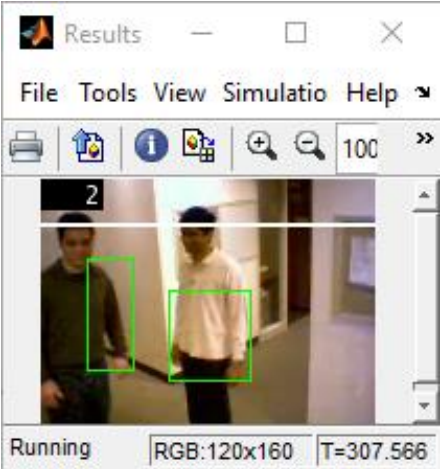

(c)

Gambar 7. Video 2 : Vipmen.avi dengan algoritma Lucas-Kanade (a). Video original (b). Video threshold (c). Video results

Tabel analisa pengujian untuk kedua algoritma dengan menggunakan simulai parameter pada tabel 1 dapat dilihat pada tabel 2. Kedua algoritma dari sisi pelacakan objek, tampak kedua algoritma sama-sama dapat mendeteksi dan mengenali objek, serta dapat mengetahui jumlah objek yang ada.

Tabel 2. Analisa Pengujian

\begin{tabular}{|c|c|c|}
\hline Kriteria Analisa & Algoritma Horn-Schunck & Algoritma Lucas-Kanade \\
\hline Threshold & $\begin{array}{l}\text { Algoritma berhasil melakukan } \\
\text { thresholding terhadap objek } \\
\text { bergerak yang digunakan } \\
\text { dalam penelitian. Objek yang } \\
\text { digunakan dalam penelitian } \\
\text { berhasil dikenali bentuknya. }\end{array}$ & $\begin{array}{l}\text { Algoritma berhasil melakukan } \\
\text { thresholding dari objek yang } \\
\text { digunakan. Dari pengujian } \\
\text { berhasil mengenali bentuk } \\
\text { objek, sehingga pada tahap } \\
\text { result dapat dikenali berapa } \\
\text { jumlah objek yang melintas } \\
\text { atau terdeteksi. }\end{array}$ \\
\hline Results & $\begin{array}{l}\text { Algoritma berhasil melakukan } \\
\text { pelacakan objek dengan } \\
\text { mengidentifikasi } \\
\text { jumlah objek yang melintas } \\
\text { dalam suatu frame. }\end{array}$ & $\begin{array}{l}\text { Algoritma berhasil } \\
\text { mengidentifikasi objek yang } \\
\text { melintas bahkan dapat } \\
\text { menentukan berapa jumlah } \\
\text { objek yang melintas dalam } \\
\text { frame. }\end{array}$ \\
\hline
\end{tabular}

Tabel 3 merupakan perbandingan Profile Report antara algoritma Horn-Schunck dan algoritma Lucas-Kanade. Dari pengujian yang dilakukan terhadap simulasi waktu untuk masingmasing algoritma dengan dua video yang digunakan menggunakan durasi waktu 110 sampai 120. Dimana dari semua pengujian terhadap durasi waktu yang dilakukan memiliki hasil yang sama, hanya saja yang membedakan pada nilai total waktu record yang diperoleh. Berdasarkan analisa di Tabel 2 nampak kedua algoritma berhasil melakukan identifikasi objek dan mendeteksi berapa jumlah objek yang melintas. Tetapi dari perbandingan Tabel 3 tampak algoritma LucasKanade memiliki total waktu record lebih cepat dalam mendeteksi objek dibandingkan dengan algoritma Horn-Schunck. Sebagai contoh video Vipmen, dengan waktu simulasi 116 untuk LucasKanade menghasilkan total waktu pendeteksian dan pengenalan objek lebih cepat yaitu sebesar 25.14 detik sedangkan Horn-Schunck menghasilkan total waktu pendeteksian dan pengenalan objek sebesar 27.58 detik. 
Tabel 3. Perbandingan Profile Report

\begin{tabular}{|c|c|c|c|}
\hline $\begin{array}{l}\text { Nama } \\
\text { Video }\end{array}$ & Kriteria Penilaian & $\begin{array}{c}\text { Profile Report } \\
\text { Algoritma Horn- } \\
\text { Schunck }\end{array}$ & $\begin{array}{c}\text { Profile Report } \\
\text { Algoritma } \\
\text { Lucas-Kanade }\end{array}$ \\
\hline 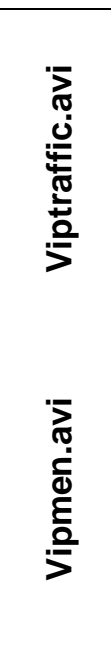 & $\begin{array}{l}\text { Simulation Times } \\
\text { Total Recorded Time } \\
\text { Number of Block Methods } \\
\text { Number of Internal Methods } \\
\text { Number of Model Methods } \\
\text { Number of Nonvirtual Subsystem Methods } \\
\text { Clock Precision } \\
\text { Clock Speed } \\
\text { Simulation Times } \\
\text { Total Recorded Time } \\
\text { Number of Block Methods } \\
\text { Number of Internal Methods } \\
\text { Number of Model Methods } \\
\text { Number of Nonvirtual Subsystem Methods } \\
\text { Clock Precision } \\
\text { Clock Speed }\end{array}$ & $\begin{array}{l}T=112.333 \\
15.63 \text { detik } \\
105 \\
5 \\
9 \\
15 \\
0.00000005 \text { detik } \\
2000 \mathrm{MHz} \\
\mathrm{T}=116.233 \\
27.58 \text { detik } \\
105 \\
5 \\
9 \\
15 \\
0.00000005 \text { detik } \\
2000 \mathrm{MHz}\end{array}$ & $\begin{array}{l}T=110.333 \\
13.92 \text { detik } \\
105 \\
5 \\
9 \\
15 \\
0.00000005 \text { detik } \\
2000 \mathrm{MHz} \\
\mathrm{T}=116.100 \\
25.14 \text { detik } \\
105 \\
5 \\
9 \\
15 \\
0.00000005 \text { detik } \\
2000 \mathrm{MHz}\end{array}$ \\
\hline
\end{tabular}

\section{Kesimpulan}

Pelacakan objek dengan menggunakan algoritma Horn-Schunck dan algoritma LucasKanade berhasil mendeteksi objek bergerak dari dua video yang digunakan dalam penelitian. Kedua algoritma berhasil mengetahui berapa jumlah objek yang melintas dalam frame. Perhitungan jumlah objek yang melintas dilihat dari objek yang melewati garis batas pada hasil uji coba result. Dalam segi waktu pelacakan dengan durasi waktu yang sama 110 sampai 120 ternyata algoritma Lucas-Kanade lebih cepat dalam mengenali objek dibandingkan dengan algoritma Horn-Schunck. Penelitian dilakukan menggunakan data objektif dari dua video. Penelitian dengan menggunakan Simulink Matlab untuk kedua algoritma ini hanya dapat dilakukan pada video dengan resolusi dibawah 200x200 dan frame antara 10-30 fps.

Pengembangan selanjutnya untuk penelitian pelacakan objek adalah dapat menggunakan video dengan ukuran resolusi dan frame yang lebih besar serta dapat menggunakan kamera yang diletakkan pada posisi dan jarak kamera yang lebih baik. Dapat menggunakan algoritma Optical Flow lainnya untuk dibandingkan dengan algoritma Lucas-Kanade dalam pengenalan objek.

\section{Referensi}

[1] K. M. Kaloh, V. C. Poekoel and M. D. Putro. 2018. Perbandingan Algoritma Background Substraction dan Optical Flow Untuk Deteksi Manusia. E-Journal Teknik Informatika, vol. 13, no. 1, pp. 1-9

[2] W. Supriyatin, Y. Rafsyam and Jonifan. 2017. Analisis Pelacakan Objek Menggunakan Background Estimation Pada Kamera Diam dan Bergerak. ORBITH, vol. 13, no. 2, pp. 124130.

[3] A. Balasundaram, S. A. Kumar and S. M. Kumar. 2019. Optical Flow Based Object Movement Tracking. International Journal of Engineering and Advanced Technology (IJEAT), vol. 9, no. 1, pp. 3913-3916.

[4] A. M. Suzan and G. Prathibha. 2017. Detection And Tracking of Moving Objects Using Hybrid Model (GMM \& Horn-Schunck). International Journal of Electrical and Electronic Engineering \& Telecommunications (IJEETC), vol. 6, no. 2, pp. 37-42.

[5] Wikipedia, "Lucas-Kanade Method," Wikipedia, 14 December 2019. [Online]. Available: https://en.m.wikipedia.org/wiki/Lucas\%E2\%80\%93Kanade_method. [Accessed 08 April 2020]. 
[6] Y. Syarif, R. R. Isnanto and K. I. Satoto. 2013. Perangkat Lunak Pengendali Pointer Menggunakan Pelacakan Mata (Eye Tracking) Dengan Algoritma Lucas Kanade. TRANSIENT, vol. 2, no. 3, pp. 714-719.

[7] W. Supriyatin. 2019. Analisis Perbandingan Pelacakan Objek Menggunakan Optical Flow dan Background Estimation Pada Kamera Bergerak. ILKOM Jurnal IImiah , vol. 11, no. 3, pp. 191-199.

[8] W. A. W. W. Supriyatin and I. Astuti. 2018. Comparative Analysis of Tracking Objects Using Optical Flow and Background Estimation on Silent Camera. KINETIK, vol. 3, no. 2, pp. 91100.

[9] W. Supriyatin and W. W. Ariestya. 2016. Analisis Pelacakan Objek Mobil Dengan Optical Flow Pada Kamera Diam dan Bergerak," Seminar Riset Teknologi Informasi (SRITI), pp. 48-56.

[10] E. Sutanty and A. Rosemala. 2016. Analisis Perbandingan Algoritma Optical Flow dan Background Estimation untuk Pendeteksian Objek pada Video. Jurnal IImiah KOMPUTASI, vol. 15, no. 1, pp. 15-21.

[11] Z. Fan, "Optical Flow Estimation With Horn-Schunck Method," 25 March 2015. [Online]. Available: https://fzheng.me/2015/03/25/optical-flow/. [Accessed 04 May 2020].

[12] Wikipedia, "Horn-Schunck method," Wikipedia, 05 February 2020. [Online]. Available: https://en.m.wikipedia.org/wiki/Horn-Schunck_method. [Accessed 04 May 2020]. 